wishing to be considered for examination must apply online at www.abts.org.

To be admissible for the Part II (oral) examination, a candidate must have successfully completed the Part I (written) examination.

A candidate applying for admission to the certifying examination must fulfill all the requirements of the Board in force at the time the application is received. Please address all communications to the American Board of Thoracic Surgery, 633 North St Clair Street, Suite 2320, Chicago, IL 60611 (telephone: 312-202-5900).

\section{Requirements for Recertification/Maintenance of Certification}

$\mathrm{D}$ iplomates of the American Board of Thoracic Surgery who plan to participate in the Recertification/Maintenance of Certification process must hold an active medical license and must hold clinical privileges in thoracic surgery. In addition, a valid certificate is an absolute requirement for entrance into the recertification/maintenance of certification process. If your certificate has expired, the only pathway for renewal of a certificate is to take and pass the Part I (written) and the Part II (oral) certifying examinations.

The American Board of Thoracic Surgery will no longer publish the names of individuals who have not recertified in the American Board of Medical Specialties directories. The Diplomate's name will be published upon successful completion of the recertification/maintenance of certification process.

The CME requirements include 70 Category I credits in either cardiothoracic surgery or general surgery earned during the 2 years prior to application. SESATS and SESAPS are the only self-instructional materials allowed for credit. Category II credits are not allowed. The Physicians Recognition Award for recertifying in general surgery is not allowed in fulfillment of the CME requirements. Interested individuals should refer to the Booklet of Information for a complete description of acceptable CME credits.

Diplomates should maintain a documented list of their major cases performed during the year prior to application for recertification. This practice review should consist of 1 year's consecutive major operative experiences. If more than 100 cases occur in 1 year, only 100 should be listed.

Candidates for recertification/maintenance of certification will be required to complete all sections of the SESATS selfassessment examination. It is not necessary for candidates to purchase SESATS individually because it will be sent to candidates after their application has been approved.

Diplomates may recertify the year their certificate expires, or if they wish to do so, they may recertify up to 2 years before it expires. However, the new certificate will be dated 10 years from the date of expiration of their original certificate or most recent recertification certificate. In other words, recertifying early does not alter the 10 -year validation.

Recertification/maintenance of certification is also open to Diplomates with an unlimited certificate and will in no way affect the validity of their original certificate.

The deadline for submission of applications for the recertification/maintenance of certification process is May 10 each year. A brochure outlining the rules and requirements for recertification/maintenance of certification in thoracic surgery is available upon request from the American Board of Thoracic Surgery, 633 North St Clair Street, Suite 2320, Chicago, IL 60611; telephone: 312-202-5900; fax: 312-202-5960; E-mail: info@abts.org. The booklet is also published on the Web site: www.abts.org 